\title{
Pseudarthrosis of the Cervical Spine: Risk Factors, Diagnosis and Management
}

\author{
Dante Leven, Samuel K. Cho \\ Department of Orthopaedic Surgery, Icahn School of Medicine at Mount Sinai, New York, NY, USA
}

Cervical myelopathy and radiculopathy are common pathologies that often improve with spinal decompression and fusion. Postoperative complications include pseudarthrosis, which can be challenging to diagnose and manage. We reviewed the literature with regard to risk factors, diagnosis, controversies, and management of cervical pseudarthrosis.

Keywords: Cervical spine; Complications; Nonunion; Risk factors; Fusion

\section{Introduction}

Spinal fusion was first described in the early 1900's for the treatment of Pott's disease in the thoracolumbar spine [1-3]. The anterior approach for cervical arthrodesis was introduced in the 1950's and subsequently became increasingly popular as it allowed access to anterior pathology [4-7]. Despite technological advancements in spinal instrumentation and biologics, failed spinal fusion rates range as high as $50 \%$, and the number of fusion procedures performed each year is increasing [5,8-11].

Pseudarthrosis refers to a failure of fusion after an index procedure intended to obtain spinal arthrodesis $[4,5,12]$. The term suggests the presence of a false joint, although it is commonly used to describe a lack of fusion that occurs after an attempted arthrodesis. As not all patients with pseudarthrosis are symptomatic, the current literature likely underestimates the true incidence of this complication $[8,9,13,14]$. Furthermore, multiple studies have shown that patients with pseudarthrosis are asymptomatic in approximately $30 \%$ of cases $[8,11,15]$. None- theless, pseudarthrosis remains a leading cause of pain postoperatively and accounts for $45 \%-56 \%$ of revisions [16-19]. The literature has also shown a direct correlation between boney fusion and successful clinical outcomes $[8,10,12,13,20]$.

\section{Pathoanatomy and Risk Factors}

Degeneration of the cervical spine may lead to cervical spondylotic myelopathy and/or radiculopathy. Degeneration of the intervertebral disc, uncovertebral joint, facet joint, ligamentum flavum, and posterior longitudinal ligament can cause spinal cord compression, myelopathy, and instability of the spine $[7,10,12,21,22]$. With extensive multi-level pathology and instability, obtaining a successful fusion may become more challenging. The most caudal level is involved in over $80 \%$ of pseudarthrosis occurring in multi-level arthrodesis [12]. This may be due to higher contact stress at the graft-body interface. Patient and surgical factors that impair vascularity, decrease stability, or increase stress through a fusion site can interfere with the

Received Oct 11, 2015; Accepted Oct 13, 2015

Corresponding author: Samuel K. Cho

Department of Orthopaedic Surgery, Icahn School of Medicine at Mount Sinai,

5 East $98^{\text {th }}$ Street, Box 1188 , New York, NY 10029, USA

Tel: +1-212-241-0276, Fax: +1-646-537-8531, E-mail: samuel.cho@mountsinai.org 
intended arthrodesis.

The true etiology of pseudarthrosis is often not clear. Risk factors associated with pseudarthrosis following an arthrodesis include patient factors, multilevel fusions, type of bone graft, approach, and type of instrumentation [10-12,23-28].

\section{Patient factors}

Patient issues of importance include smoking, obesity, diabetes, metabolic abnormalities, chronic steroid use, osteoporosis, malnutrition, chronic illnesses, age, and vascular abnormalities [12,29-31]. Older age has been associated with increased postoperative complications, although not with pseudarthrosis [32]. Interestingly, younger age has been significantly associated with a higher rate of symptomatic pseudarthrosis (43.8 years vs. 52.1 years; $p<0.01$ ) [12]. Although the reason is not entirely clear, this may be related to higher physical demands on the implant and fusion site or higher expectations in younger patients.

Smoking is associated with higher rates of pseudarthrosis [30,31]. In a study of 160 patients who underwent anterior cervical corpectomy, current smoking status was an independent risk factor for pseudarthrosis as well as infection and longer lengths of stay [31]. Higher rates of fusion in nonsmokers were reported in smokers following anterior cervical discectomy and fusion (ACDF) with allograft ( $81 \%$ vs. $62 \%, p<0.05)$ [30].

Contrary to these studies, smoking was not associated with decreased fusion rates in patients undergoing posterior fusion with lateral mass and iliac crest grafting [33]. The authors suggested that in smokers, posterior spinal fusion should be considered to optimize fusion rates. Regardless, smoking has shown to increase the risk for nonunion in multiple studies as well as rates of other postoperative complications, such as infection, wound complications, and longer length of stay [31]. Thus, patients should be counseled appropriately during preoperative discussions.

Although duration and severity of symptoms and specific types of lesions seen in patients with ossification of the posterior longitudinal ligament (OPLL) have been negatively associated with patient outcomes, these factors have not been shown to be associated with pseudarthrosis [34]. These factors should still be considered in the process of judicious surgical planning (Table 1).
Table 1. Risk factors for pseudarthrosis

\begin{tabular}{l}
\hline Smoking \\
Metabolic syndrome \\
Diabetes \\
Obesity \\
Younger age \\
Chronic steroid use \\
Malnutrition \\
\hline
\end{tabular}

\section{Surgical considerations}

Patients with progressive cervical radiculopathy or myelopathy often benefit from surgery and each surgical approach has specific benefits and complications to consider. There is considerable controversy between anterior, posterior, or combined anterior-posterior approaches. Planning the optimal surgical technique is dictated by, the number of involved levels, location of compression, underlying deformity sagittal and coronal alignment, severity of disease, presence of axial pain, patient baseline factors, and surgeon preference $[22,34,35]$.

\section{Anterior versus posterior and combined approaches}

ACDF and anterior cervical corpectomy and fusion (ACCF) allow access to the majority of compressive pathology (intervertebral discs, ventral osteophytes, and OPLL), restoration of cervical lordosis, and decompression over kyphotic deformities. Efficacy, neurologic improvement, and favorable outcomes have been reported [5,6,11,20,21,24,35-38]. Classically, overall complication rates with anterior procedures are higher than with posterior procedures $[8,11,20,21,24,25,27,28,39,40]$. Recent reviews have shown comparable complication rates between anterior and posterior procedures with higher complication rates in combined anterior-posterior procedures. Zhu et al. [24] compared anterior $(n=245)$ and posterior $(\mathrm{n}=285)$ procedures, and reported a significantly higher reoperation rate in the anterior group $(21 / 245,8.57 \%$ vs. $1 / 285,0.3 \% ; p<0.001)$. Of the 21 patients who underwent reoperation, 13/21 (62\%) were for pseudarthrosis, 7/21 (33.3\%) for adjacent deterioration, and 1/21 (4.8\%) for loosening of implant. In the posterior group only $1(0.3 \%)$ required reoperation for radiculopathy due to a new herniation, consistent with other studies [19,40]. However, 
postoperative neurologic function and outcomes were more favorable in the anterior group $(p<0.05)$.

Anterior plating has been shown to improve fusion rates with ACDF and ACCF in several studies [29,41-43]. A retrospective review of 540 patients who underwent anterior cervical plating with cortical allograft showed fusion rates of $96 \%$ and $91 \%$ for one and two level ACDF with anterior plate fixation, respectively, compared with $90 \%$ and $72 \%$ without anterior fixation, respectively $(p<0.05)$ [41]. A meta-analysis of 2,682 patients assessed fusion rates in anterior cervical interbody fusion and corpectomy procedures with and without plate fixation [42]. Plate fixation improved fusion rates for all one, two, and three level ACDF's ( $p<0.001,0.001$, and 0.05 , respectively). They also concluded that for three level procedures, corpectomy with plate placement was associated with higher fusion rates than discectomy with plate placement $(82.5 \%$ vs $96.2 \%, p<0.05)$. Thus, plate fixation has become widely accepted in both ACDF and ACCF procedures.

A posterior approach may avoid the complications associated with anterior arthrodesis and is essentially an indirect decompression. Thus, the approach is not recommended in patients with underlying cervical kyphosis. The posterior approach is associated with higher postoperative pain, due to greater muscle trauma and denervation, a less cosmetic scar and a lack of direct access to anterior structures [44].

Pseudarthrosis rates are lower following posterior procedures as compared with anterior procedures [25,38]. Other complications, such as neurovascular injury, screw malposition, iatrogenic foraminal stenosis, and adjacent segment degeneration, are more common than pseudarthrosis in posterior procedures $[19,27,28,40,44]$. Although pseudarthrosis rates are typically lower after posterior procedures, patients undergoing posterior arthrodesis are reportedly 7.5-times more likely to undergo reoperation due to adjacent segment disease (ASD) than patients undergoing posterior decompression only, and 3.0-times more likely to undergo reoperation due to ASD than patients undergoing anterior arthrodesis [45]. Callahan et al. [46] studied outcomes after posterolateral bone-grafting and wiring and reported fusion rates of 96\% (50/52). Heller et al. [47] compared laminoplasty with laminectomy and fusion in patients with multi-level CSM and recommended laminoplasty as no complications occurred in this group. Complication rates were higher in the laminectomy and fusion group and included nonunion (38\%),
ASD, implant failure, and donor site pain.

A systematic review concluded that both laminectomy with fusion and laminoplasty produce similar outcomes and complication rates for patients with multi-level cervical pathology [48]. Pseudarthrosis was seen in 1\% (1/82), $8 \%(2 / 26)$, and $38 \%(5 / 13)$ in the three studies that reported on this complication. Overall, both surgical options were similarly effective, although the quality of evidence was graded as low as only retrospective cohort studies were examined.

If anterior and posterior pathology are present, a combined approach may be indicated. An analysis of the combined anterior-posterior and anterior only approaches reported improved sagittal alignment and better maintenance of the correction angle in the combined group with a follow-up of two years ( $p=0.001$, postoperatively; $p=0.043$, two-year follow-up). Lower rates of pseudarthrosis ( $20 \%$ vs. $0 \%, p=0.034$ ), cage subsidence ( $40 \%$ vs. $6.7 \%, p=0.025)$, hardware-related complications $(26.7 \%$ vs. $0 \%, p=0.013)$, and clinical outcomes $(p=0.046)$ were found in the combined group. However, operative time was significantly longer (86 minutes versus 266 minutes, $p<0.05)$ and blood loss was greater $(188 \mathrm{~mL}$ vs. $329 \mathrm{~mL}$, $p<0.05)$ in the combined group. These factors should be considered when planning a combined procedure (Table 2) $[19,24,32,40,47,49-52]$.

\section{Multi-level cervical pathology}

Increasing rates of pseudarthrosis with increasing levels of fusion have been reported [10,43,53]. A report of one and two level ACDF's without instrumentation demonstrated a pseudarthrosis rate of $11 \%$ and $28 \%$, respectively [43]. Another study reviewed 122 patients treated with ACDF with autogenous iliac crest bone graft and reported that the risk was significantly greater in multiple-level arthrodesis than after single-level arthrodesis (24/195, $p<0.01)$ [10]. Similarly, high pseudarthrosis rates were reported in a review of patients undergoing three and four level ACDF's with iliac crest autograft and locking plates. Pseudarthrosis was found in 53\% (8/16) of patients, although less than half (3/8) had enough pain to warrant a revision procedure [53]. The author concluded that although plating may improve fusion rates for ACDF's, three and four level fusions appear to have unacceptably high failure rates. A systematic review compared laminoplasty with corpectomy and fusion in patients with cervical 
Table 2. Anterior vs posterior vs combined cervical fusion

\begin{tabular}{|c|c|c|}
\hline Study & Population & Results \\
\hline $\begin{array}{l}\text { Zhu et al. [24] } \\
\text { Level III }\end{array}$ & $\begin{array}{l}n=245 \text { (anterior) } \\
n=285(285)\end{array}$ & $\begin{array}{l}\text { Anterior: } 8.57 \% \text { reoperation rate, higher J0A score postoperative } \\
(p<0.05) \\
\text { Posterior: } 0.3 \% \text { reoperation rate }\end{array}$ \\
\hline $\begin{array}{l}\text { Song et al. [49] } \\
\text { Level III }\end{array}$ & $\mathrm{n}=302$ (anterior, posterior, combined) & $\begin{array}{l}\text { Anterior: } 11 \% \text { reoperation rate } \\
\text { Posterior: } 19 \% \text { reoperation rate } \\
\text { Combined: } 37 \% \text { reoperation rate }\end{array}$ \\
\hline $\begin{array}{l}\text { Heller et al. [47] } \\
\text { Level III }\end{array}$ & $\begin{array}{l}n=13 \text { laminoplasty } \\
n=13 \text { laminectomy with fusion }\end{array}$ & $\begin{array}{l}\text { Laminoplasty: } 0 \text { complications } \\
\text { Laminectomy: } 14 \text { complications, 38\% (5/13) due to pseudarthrosis }\end{array}$ \\
\hline $\begin{array}{l}\text { Coe et al. [50] } \\
\text { Level III } \\
\text { Systematic review }\end{array}$ & $\begin{array}{l}\text { Posterior lateral mass screw vs. wiring } \\
\text { Systematic review } 20 \text { articles (18 case } \\
\text { series, } 2 \text { retrospective comparative) }\end{array}$ & $\begin{array}{l}\text { Posterior wiring: }<1 \% \text { complication rate, } 97 \% \text { fusion rate } \\
\text { Lateral mass screws: }<1 \% \text { complication rate, } 100 \% \text { rusion rate }\end{array}$ \\
\hline $\begin{array}{l}\text { Edwards et al. [51] } \\
\text { Level III }\end{array}$ & $\begin{array}{l}n=13 \text { (anterior corpectomy) } \\
n=13 \text { (laminoplasty) } \\
\text { all }>3 \text { levels }\end{array}$ & $\begin{array}{l}\text { Anterior: } 69 \%(9 / 13) \text { complication rate, } 0.9 \text { grade improvement } \\
\text { Nurick grade } \\
\text { Posterior: } 7.7 \%(1 / 13) \text { complication rate, } 1.6 \text { grade improvement } \\
\text { in Nurick grade }\end{array}$ \\
\hline $\begin{array}{l}\text { Fehlings et al. [32] } \\
\text { Level III }\end{array}$ & $\begin{array}{l}n=176 \text { (anterior) } \\
n=107 \text { (posterior) } \\
n=19 \text { (combined) }\end{array}$ & $\begin{array}{l}\text { Anterior vs. posterior vs combined: } \\
11 \%, 19 \%, 37 \% \text { complication rate (significant higher for combined } \\
\text { anterior-posterior procedure } p<0.05 \text { ) }\end{array}$ \\
\hline $\begin{array}{l}\text { Woods et al. [52] } \\
\text { Level III }\end{array}$ & $\begin{array}{l}\mathrm{n}=82 \text { (laminectomy with fusion) } \\
\mathrm{n}=39 \text { (laminoplasty) }\end{array}$ & $\begin{array}{l}\text { Laminoplasty: } 13 \% \text { complication, } 5 \% \text { revision } \\
\text { Laminectomy: } 9 \% \text { complication, } 1 \%(1 / 18) \text { due to pseudarthrosis, } \\
2 \% \text { revision }\end{array}$ \\
\hline $\begin{array}{l}\text { Liu et al. [40] } \\
\text { Level III } \\
\text { Systematic review }\end{array}$ & $\begin{array}{l}n=330 \text { (anterior) } \\
n=323 \text { (posterior) }\end{array}$ & $\begin{array}{l}\text { Anterior vs. posterior: } 37 \% \text { complication rate vs. } 25.4 \%(p<0.05) \text {, } \\
\text { reoperation rate } 8.1 \% \text { vs } 0.9 \% \text { ( } p<0.05), 4.8 \% \text { vs. } 0 \% \text { pseudarthrosis, } \\
\text { postoperative J0A score higher in anterior group for subgroup with } \\
2 \text { or } 3 \text { spinal levels, (0.67 mean difference } p<0.05) \text {, no difference } \\
\text { in subgroup with > or = to } 3 \text { spinal levels }(p>0.05), 66 \% \text { posterior } \\
\text { reoperations due to new disc herniation, } 33 \% \text { posterior hematoma. } \\
\text { Authors conclusion: similar results and outcomes between the } \\
\text { groups. }\end{array}$ \\
\hline $\begin{array}{l}\text { Liu et al. [19] } \\
\text { Level III } \\
\text { Systematic review }\end{array}$ & $\begin{array}{l}\mathrm{n}=248 \text { (anterior corpectomy) } \\
\mathrm{n}=321 \text { (laminoplasty) }\end{array}$ & $\begin{array}{l}\text { Anterior vs. posterior: } 16.5 \% \text { vs } 0.9 \% \text { reoperation rate }(p, 0.01 \text { for } \\
\text { both subgroups between } 2 \text { and } 3 \text { spinal levels and greater than } 3 \\
\text { spinal levels), pseudarthrosis } 10.1 \% \text { in anterior group (accounting for } \\
56.1 \% \text { of reoperations), cause of reoperation in posterior group new } \\
\text { disc herniation. } \\
\text { Authors recommend corpectomy or posterior fusion for }<3 \text { spinal } \\
\text { levels, laminoplasty for }>\text { or = to } 3 \text { spinal levels due to lower } \\
\text { complication rate }\end{array}$ \\
\hline
\end{tabular}

JOA, Japanese Orthopaedic Association.

myelopathy or OPLL (the groups were divided into 2- or 3 -level involvement and $\geq 3$-level involvement). The authors found significantly lower complications and reoperation rates, and less surgical trauma in the laminoplasty group $(p<0.05)[19,40]$. A high percentage $(56.1 \%)$ of reoperations were due to pseudarthrosis in the corpectomy group. The authors suggested that laminoplasty may be a safer option for $>3$ spinal levels, and either approach may be used for $<3$ levels. Complication rates were higher with anterior corpectomy, but postoperative neurological re- covery and patient outcome scores were superior to posterior procedures, specifically in patients with $>50 \%-60 \%$ spinal cord compression or $<3$ spinal level myelopathy or OPLL.

\section{Bone grafting and biologics}

Both the type of bone graft and use of biologic agents have been associated with the development of pseudarthrosis. Samartzis et al. [54] compared tricortical allograft with 
autogenous iliac crest tricortical graft in patients undergoing two- or three-level ACDF. Fusion rates and outcomes were assessed at a mean of 16 months. Almost all (78/80, 97.5\%; $p<0.05)$ achieved fusion and pseudarthrosis occurred in two patients who underwent allograft fusion, although this was not statistically significant. Regardless, clinical outcomes were similar between the two groups and were excellent and good in $88.8 \%$ of patients.

The same group also examined fusion rates comparing allograft and autograft following one level anterior cervical fusion with plate fixation [55]. They compared radiographic fusion at 12 months, risk factors, and patient reported outcomes between the two groups; 35 patients received allograft while 31 patients received autograft. Fusion was $100 \%$ in the allograft group and $90.3 \%$ in the autograft group with no statistically significant difference $(p>0.05)$. Clinical outcomes were also not statistically different between the two groups. Typically, higher pseudarthrosis rates are seen when using allograft versus autograft with reported differences of $17 \%-27 \%$ versus $41 \%-62 \%$, comparing allograft and autograft, respectively $[25,56,57]$.

Only one prospective study has been reported which compared recombinant human bone morphogenetic protein-2 (rhBMP-2) to autograft in patients undergoing ACDF [58]. Fusion rates of rhBMP-2 (0.9 mg per level) were slightly better than the use of iliac crest autograft with pseudarthrosis occurring in one of 30 receiving rhBMP-2 with allograft and 2 of 36 receiving iliac crest autograft. However, anterior neck swelling was reported in half of the rhBMP-2 patients. The United States Food and Drug Administration released a public health notification due to 38 reports of complications occurring with the use of rhBMP-2 associated with swelling, airway compression, neurologic injury, dysphagia, and dysphonia. Currently, rhBMP-2 is only approved for lumbar interbody fusion in skeletally mature patients with degenerative disc disease from L2-S1. rhBMP-7 is approved as an alternative to autograft for immunocompromised patients undergoing revision posterolateral lumbar fusion where autologous bone or bone marrow harvest are not expected to promote fusion [59]. Furthermore, issues with regard to higher cost, potential side effects, carcinogenesis, and inconclusive recommendations with regard to dosing and methods of insertion have dissuaded most spine surgeons from routinely utilizing rhBMP with cervical spinal arthrodesis.

\section{Diagnosis}

An accurate diagnosis of cervical pseudarthrosis can be difficult prior to a surgical exploration. High rates of asymptomatic patients and diagnostic tests lacking high sensitivity and specificity can cloud the diagnostic workup. Regardless, if patients develop persistent symptoms or pain postoperatively, pseudarthrosis ought to be considered $[4,8-10,12,14,15,23,60]$.

The work-up starts with a careful history and physical examination. Symptoms classically present as mechanical neck pain worsened by motion with radiation into the arm $[8,12]$, although this can also occur with other underlying pathology. Disease progression, infection, implant failure, ASD, and postoperative pain syndromes should be ruled out.

The most common causes of axial or radicular symptoms after ACDF are pseudarthrosis and ASD, although as previously mentioned a relatively high percentage of patients with pseudarthrosis are asymptomatic $[4,12,13]$. Younger age at the index arthrodesis is associated with a higher incidence of symptomatic pseudarthrosis. However, symptoms may vary which complicates the diagnostic work up. Lowery et al. [8] reported that in patients with pseudarthrosis, 27\% felt the same and 64\% felt worse. Patients who develop this complication often develop a various relapse in symptoms. Several reports have documented symptomatic cases ranging from $70 \%-$ $80 \%[10,13,53]$. Newman [13] reported on 23 patients who developed pseudarthrosis after an anterior fusion and 16/23 (69.6\%) had persistent symptoms. Thus, spine surgeon must be mindful, as $20 \%-30 \%$ of patients may be asymptomatic.

The initial work-up generally includes radiographs (lateral and flexion-extension views), thin-cut computed tomography (CT), and some recommend the use of magnetic resonance imaging (MRI), nuclear studies, or ultrasound in special situations [12,14,39,61]. Although imaging is important in the diagnostic work-up, the true diagnosis is only made upon surgical exploration [39].

Radiographic signs of pseudarthrosis include a lack of bridging trabeculae between the host bone and graft, motion exceeding $1 \mathrm{~mm}$ or $2 \mathrm{~mm}$ between spinous processes on maximal flexion-extension views and changes in the Cobb angles [12,14,21,39]. Measuring the distance between the tips of the spinous processes of the fused levels in flexion and extension views has also been documented 
Table 3. Planning surgical revision

\begin{tabular}{l}
\hline Approach \\
Number of levels \\
Prior complications \\
Medical stability \\
Kyphosis or sagittal/coronal malalignment (consider anterior revision or posterior laminectomy/fusion) \\
Graft/cage migration (consider anterior revision) \\
Type of bone graft (evidence supports autograft) \\
Current symptoms (axial pain $\rightarrow$ may improve with laminectomy/fusion if indicated, radicular pain $\rightarrow$ base approach on location of compression) \\
\hline
\end{tabular}

as an accurate diagnostic method [21]. Cannada et al. [21] reported a specificity of $89 \%$ and sensitivity of $91 \%$ using this method, while changes in Cobb angle of $>2$ degrees resulted in a specificity of $39 \%$ and a sensitivity of $82 \%$. However, a change in Cobb angle of $>4$ degrees significantly improves the specificity with a positive predictive value of $100 \%$. Some studies also suggest using higher magnification (150\% or $200 \%)$ on radiographic evaluation to better visualize an underlying pseudarthrosis [62].

CT scans are typically utilized when radiographic studies are inconclusive. While metallic artifact may obscure the assessment of fusion, the interobserver reliability of fine-cut CT is better than with flexion-extension radiographs $[39,63]$. A prospective study evaluated intraoperative findings compared with $\mathrm{CT}$, radiographs, and MRI in patients with pseudarthrosis after ACDF; the greatest concordance was between fine-cut CT and intraoperative findings $(p<0.05)$ [39].

MRI is commonly used preoperatively during the work-up of cervical pathology, although its utility in detecting pseudarthrosis is questionable. Although artifact can obscure the surrounding tissues, it may be useful to identify surrounding structures and soft tissues for revision planning. It has been shown to be inferior to CT in diagnosing pseudarthroses, although there is no ionizing radiation, making it an appealing option. Buchowski et al. [39] found only fair interobserver reliability and moderate agreement with intraoperative findings when assessing MRI in patients with pseudarthrosis after ACDF.

There are limited studies on the use of ultrasonography in the diagnostic work-up of pseudarthrosis. In one study, ultrasonography was used to diagnose pseudarthrosis, and a sensitivity of $100 \%$ was found in patients following instrumented fusions, though the specificity was $60 \%$ [63]. Bone scans and photon emission CT scanning have shown to have limited clinical utility in the work-up of pseudarthrosis.

Diagnosing pseudarthrosis can be a challenge as many conditions may mimic this process. The current literature supports the use of flexion-extension radiographs and CT scanning as the preferred diagnostic modalities $[12,14,21,39,60]$. Special cases may warrant further studies.

\section{Management}

Symptomatic pseudarthrosis often warrants a surgical exploration and revision as successful arthrodesis is associated with improved patient outcomes [11,12,37]. In planning the revision procedure, factors that should be considered include patient comorbidities, current symptoms, underlying deformity (such as postlaminectomy kyphosis), ASD, and prior postoperative complications (such as durotomy, pseudomeningocele, wound complications, neurologic injury, and hematoma) $[5,8,10,12,39]$. The approach, number of vertebral levels, type of bone graft, and instrumentation are important considerations to clarify during surgical planning (Table 3).

Non-operative principals should be exhausted prior to revision surgery as pseudarthrosis alone is not an indication for revision. Nutritional counseling, smoking cessation, and the stabilization of medical comorbidities ought to be addressed prior to proceeding with a revision.

Although the use of allograft versus autograft in a primary cervical arthrodesis is contentious, most studies support the use of autograft in revision operations to optimize fusion potential and BMP is commonly utilized $[4,8-10,12,24,61,64]$. There is likely a limited healing potential inherent with the use of allograft as the underlying pathology is often related to diminished vascularity. 
Table 4. Comparison of revision procedures for pseudarthrosis

\begin{tabular}{|c|c|c|c|}
\hline Study & Population & Results & Comments \\
\hline $\begin{array}{l}\text { Kuhns et al. [64] } \\
\text { Level III }\end{array}$ & Posterior revision $n=33$ & $\begin{array}{l}100 \% \text { fusion. } \\
\text { No diff with BG type. } \\
\text { CSO0, SF-36, pain was absent/mild in } 52 \% \text {, } \\
\text { discomfort in } 20 \% \text {, severe in } 28 \% \text {. } \\
72 \% \text { satisfied with symptoms. }\end{array}$ & $\begin{array}{l}\text { Retrospective } \\
76 \% \text { completed outcomes data } \\
\text { No control group } \\
\text { Supports posterior revision }\end{array}$ \\
\hline $\begin{array}{l}\text { Carreon et al. [61] } \\
\text { Level III }\end{array}$ & $\begin{array}{l}\text { Anterior plate vs. } \\
\text { posterior wiring ( } n=27) \\
\text { or lateral mass }(n=93)\end{array}$ & $\begin{array}{l}\text { Anterior: } 12 / 27(44 \%) \text { required } 2 \text { nd operation } \\
\text { and } 4 \% \text { complication rate. } \\
\text { Posterior: } 2 / 93(2 \%) \text { group required } 2 \text { nd } \\
\text { operation, and } 8 \% \text { complication rate. }\end{array}$ & $\begin{array}{l}\text { Retrospective } \\
\text { No randomization } \\
\text { No clinical outcomes } \\
\text { No control group } \\
\text { Difficult to assess radiographic } \\
\text { outcomes } \\
\text { Supports posterior revision }\end{array}$ \\
\hline $\begin{array}{l}\text { Brodsky et al. [26] } \\
\text { Level III }\end{array}$ & $\begin{array}{l}\text { Anterior }(n=17) \text { vs. } \\
\text { posterior }(n=17) \text { vs. } \\
\text { revision ( } n=34)\end{array}$ & $\begin{array}{l}\text { Anterior: } 76 \% \text { fusion and excellent/good } \\
\text { in } 59 \% \text {. } \\
\text { Posterior: } 94 \% \text { fusion and excellent/good } \\
\text { in } 88 \% \text {. }\end{array}$ & $\begin{array}{l}\text { Retrospective } \\
\text { Supports posterior revision }\end{array}$ \\
\hline $\begin{array}{l}\text { Zdeblick et al. [65] } \\
\text { Level III }\end{array}$ & $\begin{array}{l}\text { anterior revision ( } \mathrm{n}=35) \\
\text { (anterior plate and ICBG } \\
\text { for }<2 \text { level, fibula } \\
\text { allograft for }>2 \text { level } \\
\text { corpectomy) }\end{array}$ & $\begin{array}{l}97 \% \text { fusion rate } \\
\text { Modified Odom scale, results: excellent } 29(83 \%) \text {, } \\
\text { good } 1(3 \%) \text {, fair } 4(11 \%) \text {, poor } 1(3 \%) \text {. } \\
\text { Complications: } 4 \text { recurrent laryngeal palsy, } \\
2 \text { wound drainage, } 1 \text { CSF leak. }\end{array}$ & $\begin{array}{l}\text { Retrospective } \\
\text { Nonvalidated modification of odom } \\
\text { scale } \\
\text { No control } \\
\text { Supports anterior revision }\end{array}$ \\
\hline $\begin{array}{l}\text { Coric et al. [66] } \\
\text { Level III }\end{array}$ & $\begin{array}{l}\text { Anterior revision }(n=19) \\
\text { allograft bone }\end{array}$ & $\begin{array}{l}\text { 100\% fusion. } \\
\text { modified Prolo scale. } \\
83.3 \% \text { excellent or good outcome. } \\
\text { Complications: } 2 \text { cases of transient hoarseness. }\end{array}$ & $\begin{array}{l}\text { Retrospective } \\
\text { Nonvalidated outcomes score } \\
\text { No control group } \\
95 \% \text { rate of follow up } \\
\text { Supports anterior revision }\end{array}$ \\
\hline $\begin{array}{l}\text { Lowery et al. [8] } \\
\text { Level III }\end{array}$ & $\begin{array}{l}\text { Anterior vs. posterior vs. } \\
\text { combined }(n=44)\end{array}$ & $\begin{array}{l}\text { Anterior group: } 45 \% \text { fusion rate, axillary pain } \\
\text { decreased by } 43 \% \text {, appendicular pain by } 56 \% \text {, } \\
\text { overall improvement in } 40 \% \text {. } \\
45 \% \text { hardware failure. } \\
\text { Posterior group: } 94 \% \text { fusion rate, axial pain } \\
\text { decreased } 77 \% \text {, appendicular pain by } 83 \%, 82 \% \\
\text { with overall improvement. } \\
12 \% \text { hardware failure. } \\
\text { Combined group: } 100 \% \text { fusion rate, axial pain } \\
\text { improved in } 68 \% \text {, appendicular pain } 65 \% \text {, overall } \\
71 \% \text {. } \\
28 \% \text { hardware failure. }\end{array}$ & $\begin{array}{l}\text { Retrospective } \\
\text { Clinical outcomes limited } \\
\text { No control group } \\
\text { Possible reporting bias } \\
\text { Supports posterior revision }\end{array}$ \\
\hline $\begin{array}{l}\text { Phillips et al. [12] } \\
\text { Level III }\end{array}$ & $\begin{array}{l}\text { Anterior ( } n=16) \text { vs. } \\
\text { posterior }(n=6) \text { revision }\end{array}$ & $\begin{array}{l}\text { Anterior group: } 88 \%(14 / 16) \text { fusion rate, } \\
5 \text { with preoperative motor weakness improved, } \\
2 \text { patients without fusion remained symptomatic. } \\
\text { Posterior group: } 100 \%(6 / 6) \text { fusion rate }\end{array}$ & $\begin{array}{l}\text { Retrospective } \\
\text { Selection bias likely } \\
\text { No control group } \\
\text { Supports anterior or posterior revision }\end{array}$ \\
\hline $\begin{array}{l}\text { Farey et al. [9] } \\
\text { Level III }\end{array}$ & Posterior revision $(n=19)$ & $\begin{array}{l}100 \% \text { fusion rate. } \\
95 \% \text { with improvement in patient outcome } \\
\text { scores. }\end{array}$ & $\begin{array}{l}\text { Retrospective } \\
\text { Nonvalidated outcome instrument } \\
\text { No control } \\
\text { Supports posterior revision }\end{array}$ \\
\hline
\end{tabular}

BG, bone graft; ICBG, iliac crest bone graft; CSO0, cervical spine outcomes questionnaire; SF-36, short form-36; CSF, cervical spinal fluid.

\section{Anterior versus posterior revision}

The surgical approach in terms of anterior versus posteri- or must be decided upon in planning the revision surgery. Proponents of the posterior approach highlight the avoidance of scar tissue and wound complications if the index 
procedure was anterior. Additionally, a posterior revision provides fresh soft tissue planes, a native fusion bed, and small studies have shown higher fusion rates $[9,12,61,64]$. Contraindications to a posterior approach include cervical kyphosis and graft or implant migration that can only be addressed from anteriorly $[8,9,12,64]$.

Although the approach is contentious, several studies have shown high fusion rates and improved patient outcomes with posterior decompression and arthrodesis $[12,16,26,61,64]$. Treating pseudarthrosis posteriorly using iliac crest or local autograft and posterior wiring or lateral mass plating has been recommended [64]. In this study, $100 \%$ fusion was achieved using this approach, with no difference between iliac crest and local bone graft. However, relatively high rates of persistent complaints of pain in these patients despite high fusion rates were reported. A retrospective review of 120 patients provided further support for posterior fusion for pseudarthrosis after ACDF [61]. Of the 27 patients who underwent a repeat anterior spinal fusion, 12 required an additional revision, while of the 93 patients treated with a posterior procedure, only 2 required an additional revision operation $(p<0.05)$. A slightly longer recovery and increased blood loss was observed in the posterior group though the higher fusion rates and lower incidence of a second revision procedure support the use of posterior fusion. Brodsky et al. [26] reported radiographic fusion rates of $76 \%$ in pseudarthrosis cases treated with anterior approach versus $94 \%$ in those treated from a posterior approach $(p<0.05)$. Another review of cases of symptomatic pseudarthrosis reported that of 16 undergoing repeat anterior procedures, successful fusion occurred in 14 [12]. The two patients who did not fuse went on to undergo posterior fusions and achieved arthrodesis.

Contrary to these reports, some studies support using an anterior approach for the revision procedure $[65,66]$. The advantages include lower rates of wound complications, access to anterior pathology and graft or implant migration, exploration of the pseudarthrosis site, and biomechanical advantages $[65,66]$. The anterior approach also allows for better restoration of normal cervical lordosis and sagittal alignment and has been associated with less postoperative stiffness and pain [65,67]. In a study of 35 patients treated for pseudarthrosis following ACDF, all cases were treated with anterior decompression and autogenous bone grafting; excellent results were reported in 29 patients, good results in one, fair results in four, and poor results in one [65].

Although pseudarthrosis can be treated with posterior or anterior approaches, the decision must be individualized based on the underlying pathology. Pseudarthrosis can also occur concomitant with other postoperative complications, such as ASD, hardware failure, or implant migration. Although the majority of the literature supports using a posterior procedure for the revision, most of these studies are low-quality retrospective studies from a single institution $[12,16,61,64]$. In the absence of kyphosis or anterior graft migration, posterior procedures may provide the most reliable option for achieving fusion, although prospective randomized studies are needed to better substantiate this question (Table 4).

\section{Conclusions}

Degenerative pathologies of the cervical spine are frequently treated with surgery with favorable patient outcomes are supported in the literature. Pseudarthrosis is a common postoperative complication that may occur after anterior or posterior procedures, and can be challenging to diagnose and manage $[8,10,12,53]$. A thorough understanding of risk factors and diagnostic work-up as presented in this review may assist the spine surgeon in guiding proper management. High fusion rates with posterior revision procedures are supported in the literature, although several variables will determine the optimal management. There is a paucity of high quality studies. So, most recommendations are limited in strength and further large multicenter studies will enhance our ability to manage this complication.

\section{Conflict of Interest}

No potential conflict of interest relevant to this article was reported.

\section{References}

1. Hibbs RA. An operation for progressive spinal deformities: a preliminary report of three cases from the service of the orthopaedic hospital. 1911. Clin Orthop Relat Res 2007;460:17-20.

2. Albee FH. Transplantation of a portion of the tibia into the spine for Pott's disease: a preliminary report 1911. Clin Orthop Relat Res 2007;460:14-6. 
3. Raizman NM, O'Brien JR, Poehling-Monaghan KL, Yu WD. Pseudarthrosis of the spine. J Am Acad Orthop Surg 2009;17:494-503.

4. Simmons EH, Bhalla SK. Anterior cervical discectomy and fusion: a clinical and biomechanical study with eight-year follow-up. J Bone Joint Surg Br 1969; 51:225-37.

5. Smith GW, Robinson RA. The treatment of certain cervical-spine disorders by anterior removal of the intervertebral disc and interbody fusion. J Bone Joint Surg Am 1958;40:607-24.

6. Cloward RB. The anterior approach for removal of ruptured cervical disks. J Neurosurg 1958;15:602-17.

7. Aronson N, Filtzer DL, Bagan M. Anterior cervical fusion by the smith-robinson approach. J Neurosurg 1968;29:396-404.

8. Lowery GL, Swank ML, McDonough RF. Surgical revision for failed anterior cervical fusions: articular pillar plating or anterior revision? Spine (Phila $\mathrm{Pa}$ 1976) 1995;20:2436-41.

9. Farey ID, McAfee PC, Davis RF, Long DM. Pseudarthrosis of the cervical spine after anterior arthrodesis: treatment by posterior nerve-root decompression, stabilization, and arthrodesis. J Bone Joint Surg Am 1990;72:1171-7.

10. Bohlman HH, Emery SE, Goodfellow DB, Jones PK. Robinson anterior cervical discectomy and arthrodesis for cervical radiculopathy: long-term follow-up of one hundred and twenty-two patients. J Bone Joint Surg Am 1993;75:1298-307.

11. Bohlman HH. Cervical spondylosis and myelopathy. Instr Course Lect 1995;44:81-97.

12. Phillips FM, Carlson G, Emery SE, Bohlman HH. Anterior cervical pseudarthrosis. Natural history and treatment. Spine (Phila Pa 1976) 1997;22:1585-9.

13. Newman M. The outcome of pseudarthrosis after cervical anterior fusion. Spine (Phila Pa 1976) 1993; 18:2380-2.

14. Martin GJ Jr, Haid RW Jr, MacMillan M, Rodts GE Jr, Berkman R. Anterior cervical discectomy with freeze-dried fibula allograft: overview of 317 cases and literature review. Spine (Phila Pa 1976) 1999;24: 852-8; discussion 8-9.

15. Mixter WJ, Barr JS. Rupture of the intervertebral disc with involvement of the spinal canal. N Engl J Med 1934;211:210-5.

16. Slizofski WJ, Collier BD, Flatley TJ, Carrera GF,
Hellman RS, Isitman AT. Painful pseudarthrosis following lumbar spinal fusion: detection by combined SPECT and planar bone scintigraphy. Skeletal Radiol 1987;16:136-41.

17. Whitecloud TS 3rd. Anterior surgery for cervical spondylotic myelopathy: Smith-Robinson, Cloward, and vertebrectomy. Spine (Phila Pa 1976) 1988;13: 861-3.

18. van Eck CF, Regan C, Donaldson WF, Kang JD, Lee JY. The revision rate and occurrence of adjacent segment disease after anterior cervical discectomy and fusion: a study of 672 consecutive patients. Spine (Phila Pa 1976) 2014;39:2143-7.

19. Liu X, Min S, Zhang H, Zhou Z, Wang H, Jin A. Anterior corpectomy versus posterior laminoplasty for multilevel cervical myelopathy: a systematic review and meta-analysis. Eur Spine J 2014;23:362-72.

20. Bohlman HH. Cervical spondylosis with moderate to severe myelopathy: a report of seventeen cases treated by robinson anterior cervical discectomy and fusion. Spine 1977;2:151-62.

21. Cannada LK, Scherping SC, Yoo JU, Jones PK, Emery SE. Pseudoarthrosis of the cervical spine: a comparison of radiographic diagnostic measures. Spine (Phila Pa 1976) 2003;28:46-51.

22. Rao RD, Gourab K, David KS. Operative treatment of cervical spondylotic myelopathy. J Bone Joint Surg Am 2006;88:1619-40.

23. Lindsey RW, Newhouse KE, Leach J, Murphy MJ. Nonunion following two-level anterior cervical discectomy and fusion. Clin Orthop Relat Res 1987; (223):155-63.

24. Zhu B, Xu Y, Liu X, Liu Z, Dang G. Anterior approach versus posterior approach for the treatment of multilevel cervical spondylotic myelopathy: a systemic review and meta-analysis. Eur Spine J 2013;22:1583-93.

25. Fernyhough JC, White JI, LaRocca H. Fusion rates in multilevel cervical spondylosis comparing allograft fibula with autograft fibula in 126 patients. Spine (Phila Pa 1976) 1991;16:S561-4.

26. Brodsky AE, Khalil MA, Sassard WR, Newman BP. Repair of symptomatic pseudoarthrosis of anterior cervical fusion. Posterior versus anterior repair. Spine (Phila Pa 1976) 1992;17:1137-43.

27. Heller JG, Silcox DH 3rd, Sutterlin CE 3rd. Complications of posterior cervical plating. Spine (Phila $\mathrm{Pa}$ 
1976) $1995 ; 20: 2442-8$.

28. Aydogan M, Enercan M, Hamzaoglu A, Alanay A. Reconstruction of the subaxial cervical spine using lateral mass and facet screw instrumentation. Spine (Phila Pa 1976) 2012;37:E335-41.

29. Bolesta MJ, Rechtine GR 2nd, Chrin AM. One- and two-level anterior cervical discectomy and fusion: the effect of plate fixation. Spine J 2002;2:197-203.

30. Hilibrand AS, Fye MA, Emery SE, Palumbo MA, Bohlman HH. Impact of smoking on the outcome of anterior cervical arthrodesis with interbody or strutgrafting. J Bone Joint Surg Am 2001;83:668-73.

31. Lau D, Chou D, Ziewacz JE, Mummaneni PV. The effects of smoking on perioperative outcomes and pseudarthrosis following anterior cervical corpectomy: Clinical article. J Neurosurg Spine 2014;21:54758.

32. Fehlings MG, Smith JS, Kopjar B, et al. Perioperative and delayed complications associated with the surgical treatment of cervical spondylotic myelopathy based on 302 patients from the AOSpine North America Cervical Spondylotic Myelopathy Study. J Neurosurg Spine 2012;16:425-32.

33. Eubanks JD, Thorpe SW, Cheruvu VK, Braly BA, Kang JD. Does smoking influence fusion rates in posterior cervical arthrodesis with lateral mass instrumentation? Clin Orthop Relat Res 2011;469:696701.

34. Yoon ST, Raich A, Hashimoto RE, et al. Predictive factors affecting outcome after cervical laminoplasty. Spine (Phila Pa 1976) 2013;38(22 Suppl 1):S232-52.

35. Sevki K, Mehmet T, Ufuk T, Azmi H, Mercan S, Erkal B. Results of surgical treatment for degenerative cervical myelopathy: anterior cervical corpectomy and stabilization. Spine (Phila Pa 1976) 2004;29:2493500.

36. Shamji MF, Massicotte EM, Traynelis VC, Norvell DC, Hermsmeyer JT, Fehlings MG. Comparison of anterior surgical options for the treatment of multilevel cervical spondylotic myelopathy: a systematic review. Spine (Phila Pa 1976) 2013;38(22 Suppl 1): S195-209.

37. Chang WC, Tsou HK, Chen WS, Chen CC, Shen CC. Preliminary comparison of radiolucent cages containing either autogenous cancellous bone or hydroxyapatite graft in multilevel cervical fusion. J Clin Neurosci 2009;16:793-6.
38. Yonenobu K, Fuji T, Ono K, Okada K, Yamamoto T, Harada N. Choice of surgical treatment for multisegmental cervical spondylotic myelopathy. Spine (Phila Pa 1976) 1985;10:710-6.

39. Buchowski JM, Liu G, Bunmaprasert T, Rose PS, Riew KD. Anterior cervical fusion assessment: surgical exploration versus radiographic evaluation. Spine (Phila Pa 1976) 2008;33:1185-91.

40. Liu X, Wang H, Zhou Z, Jin A. Anterior decompression and fusion versus posterior laminoplasty for multilevel cervical compressive myelopathy. Orthopedics 2014;37:e117-22.

41. Kaiser MG, Haid RW Jr, Subach BR, Barnes B, Rodts GE Jr. Anterior cervical plating enhances arthrodesis after discectomy and fusion with cortical allograft. Neurosurgery 2002;50:229-36.

42. Fraser JF, Hartl R. Anterior approaches to fusion of the cervical spine: a metaanalysis of fusion rates. J Neurosurg Spine 2007;6:298-303.

43. Wright IP, Eisenstein SM. Anterior cervical discectomy and fusion without instrumentation. Spine (Phila Pa 1976) 2007;32:772-4.

44. Rhee JM, Basra S. Posterior surgery for cervical myelopathy: laminectomy, laminectomy with fusion, and laminoplasty. Asian Spine J 2008;2:114-26.

45. Lee JC, Lee SH, Peters C, Riew KD. Risk-factor analysis of adjacent-segment pathology requiring surgery following anterior, posterior, fusion, and nonfusion cervical spine operations: survivorship analysis of 1358 patients. J Bone Joint Surg Am 2014;96:1761-7.

46. Callahan RA, Johnson RM, Margolis RN, Keggi KJ, Albright JA, Southwick WO. Cervical facet fusion for control of instability following laminectomy. J Bone Joint Surg Am 1977;59:991-1002.

47. Heller JG, Edwards CC 2nd, Murakami H, Rodts GE. Laminoplasty versus laminectomy and fusion for multilevel cervical myelopathy: an independent matched cohort analysis. Spine (Phila Pa 1976) 2001;26:1330-6.

48. Yoon ST, Hashimoto RE, Raich A, Shaffrey CI, Rhee JM, Riew KD. Outcomes after laminoplasty compared with laminectomy and fusion in patients with cervical myelopathy: a systematic review. Spine (Phila Pa 1976) 2013;38(22 Suppl 1):S183-94.

49. Song KJ, Johnson JS, Choi BR, Wang JC, Lee KB. Anterior fusion alone compared with combined anterior and posterior fusion for the treatment of 
degenerative cervical kyphosis. J Bone Joint Surg Br 2010;92:1548-52.

50. Coe JD, Vaccaro AR, Dailey AT, et al. Lateral mass screw fixation in the cervical spine: a systematic literature review. J Bone Joint Surg Am 2013;95:213643.

51. Edwards CC 2nd, Heller JG, Murakami H. Corpectomy versus laminoplasty for multilevel cervical myelopathy: an independent matched-cohort analysis. Spine (Phila Pa 1976) 2002;27:1168-75.

52. Woods BI, Hohl J, Lee J, Donaldson W 3rd, Kang J. Laminoplasty versus laminectomy and fusion for multilevel cervical spondylotic myelopathy. Clin Orthop Relat Res 2011;469:688-95.

53. Bolesta MJ, Rechtine GR 2nd, Chrin AM. Three- and four-level anterior cervical discectomy and fusion with plate fixation: a prospective study. Spine (Phila Pa 1976) 2000;25:2040-4.

54. Samartzis D, Shen FH, Matthews DK, Yoon ST, Goldberg EJ, An HS. Comparison of allograft to autograft in multilevel anterior cervical discectomy and fusion with rigid plate fixation. Spine J 2003;3:451-9.

55. Samartzis D, Shen FH, Goldberg EJ, An HS. Is autograft the gold standard in achieving radiographic fusion in one-level anterior cervical discectomy and fusion with rigid anterior plate fixation? Spine (Phila Pa 1976) 2005;30:1756-61.

56. Zdeblick TA, Ducker TB. The use of freeze-dried allograft bone for anterior cervical fusions. Spine (Phila Pa 1976) 1991;16:726-9.

57. Hughes SS, Pringle T, Phillips FM. Multilevel cervical corpectomy and fibular strut grafting: intermediate clinical and radiographic follow-up. Orthop Trans 1996;20:432.

58. Buttermann GR. Prospective nonrandomized comparison of an allograft with bone morphogenic protein versus an iliac-crest autograft in anterior cervical discectomy and fusion. Spine J 2008;8:426-35.

59. Schultz DG. Public Health Notification: life-threat- ening complications associated with recombinant human bone morphogenetic protein in cervical spine fusion [Internet]. Silver Spring: US Food and Drug Administration; 2015 [cited 2009 Jun 5]. Available from: http://www.fda.gov/MedicalDevices/Safety/AlertsandNotices/PublicHealthNotifications/ucm062000. htm.

60. Riley LH Jr, Robinson RA, Johnson KA, Walker AE. The results of anterior interbody fusion of the cervical spine: review of ninety-three consecutive cases. J Neurosurg 1969;30:127-33.

61. Carreon L, Glassman SD, Campbell MJ. Treatment of anterior cervical pseudoarthrosis: posterior fusion versus anterior revision. Spine J 2006;6:154-6.

62. Song KS, Piyaskulkaew C, Chuntarapas T, et al. Dynamic radiographic criteria for detecting pseudarthrosis following anterior cervical arthrodesis. J Bone Joint Surg Am 2014;96:557-63.

63. Herkowitz HN. A comparison of anterior cervical fusion, cervical laminectomy, and cervical laminoplasty for the surgical management of multiple level spondylotic radiculopathy. Spine (Phila Pa 1976) 1988;13: 774-80.

64. Kuhns CA, Geck MJ, Wang JC, Delamarter RB. An outcomes anal

ysis of the treatment of cervical pseudarthrosis with posterior fusion. Spine (Phila Pa 1976) 2005;30:2424-9.

65. Zdeblick TA, Hughes SS, Riew KD, Bohlman HH. Failed anterior cervical discectomy and arthrodesis: analysis and treatment of thirty-five patients. J Bone Joint Surg Am 1997;79:523-32.

66. Coric D, Branch CL Jr, Jenkins JD. Revision of anterior cervical pseudoarthrosis with anterior allograft fusion and plating. J Neurosurg 1997;86:969-74.

67. Tribus CB, Corteen DP, Zdeblick TA. The efficacy of anterior cervical plating in the management of symptomatic pseudoarthrosis of the cervical spine. Spine (Phila Pa 1976) 1999;24:860-4. 